\title{
Criticizing the Present through the Future or How Kurt Vonnegut Turned Science Fiction into an Art
}

\author{
M.A. Sidita (Hoxhiq) Dano \\ Assistant Professor, Department of English \\ Faculty of Foreign Languages, University of Tirana \\ Cel.00355682607694, e-mail: sidita21@yahoo.com; siditahoxhiq@hotmail.com
}

\section{Doi:10.5901/mjss.2013.v4n10p722}

\begin{abstract}
Kurt Vonnegut is one of the most known figures of the late 20th century and beginnings of the 21st century. He is one of the most prolific writers of American literature of those days. His novels are known for a usage of a wide range of subjects, starting with science and ending with environmental issues, like that of global warming.But, different from some of his well-known contemporaries, Kurt Vonnegut started writing science-fiction in paperback in order to make ends meet, as he was in a very difficult economical situation. Influenced by writers as Aldous Huxley, with "Brave New World" and also by the studies of chemistry he attended when he was at university, he used in his novels machines, super-computers, aliens, lives in other planets, etc. However, he was not just a science-fiction writer. Instead, science-fiction became a means for him to better express the ideas he had about the world. He creates other5 planets to show us what goes wrong in ours, he writes about machines that have substituted the man, he writes about scientists that are not responsible at all about the effects of their inventions. The world is not saved by scientists, but it ends because of them. That is the aim of this presentation: to show how science becomes an art in Kurt Vonnegut's fiction.
\end{abstract}

Keywords: science-fiction, technique, narration, influence, subject

"Years ago... I wrote a novel about people and machines, and machines frequently got the best of it, as machines will. (It was called Player Piano, and it was brought out again in both hard cover and paperback.) And I learned from the reviewers that I was a science-fiction writer." (Vonnegut, WFG, 1976, pg.1) This is how Kurt Vonnegut starts his essay on science fiction on the "Wamperters, Foma and Granfalloon". Kurt Vonnegut is one of the most prolific and well-known writers of the postmodern American literature. He has also been a public figure, speaking about issues like global warming, censorship, politics, free will, etc. He has been labeled as a science fiction writer, satirist, postmodernist, black humorist. But he has always denied the labels, like many other writers. Maybe the main problem for Vonnegut, of all these terms, was that of science fiction writer.

Early in his career, he was considered by the critics as a science fiction writer, for the fact that his two first novels were set in the future and included machines, robots, aliens, super computers and many other technological gadgets. When Vonnegut started writing in the 50s science-fiction was very popular, not only in literature, but also in the movies. It is considered to be a modern genre, involving space travel, robots, aliens and time travel. Being in very bad economical conditions, and being tired of working in other things but writing, he decides to write a novel. But the publishers wanted to boost the sales and emphasized the science-fiction elements to his novel. They even changed the title from "Player Piano" to "Utopia-14" to make it sound more sci-fi.

If we consider most of the novels of Kurt Vonnegut, we find a lot of elements that make him deserve the title of science-fiction writer, because in each of them we find his interest in technology, the future of mankind, the causes and effects of science development, the work of scientists, etc. On the other hand, he does not consider himself at all as a science-fiction writer. Instead he argues that all writers must know more about science, because it has already become part of our lives. What makes Vonnegut "hate" more this term is the fact that critics saw science-fiction not as a very serious genre, or "high-level literature". Vonnegut says it very clearly in "Wampeters, Foma and Granfalloon" when he says: "I supposed that I was writing a novel about life, about things I could not avoid seeing and hearing in Schenectady, a very real town awkwardly set in the gruesome now. I have been a storehead occupant of a life drawer labeled "sciencefiction" ever since, and I would like out, particularly since so many seriuos critics regularly mistake the drawer for a urinal." (Vonnegut, 1976) So, most literary critics would not admit reading science-fiction, or when they read it, they would say that it was poorly written and it was done just for the sake of filling the pages of pulp magazines that appeal to 
teenagers. Kurt Vonnegut has got an answer for that, too, when he says that these critics are educated in that way, and he blames the colleges. "And our most impressive critics have commonly been such English majors, and they are squeamish about technology to this very day. So it is natural for them to despise science fiction."

There was also another problem with the term "science-fiction". As with many other terms, most people would not agree on the definitions and what makes a writer to be called with the adjective of "science-fiction". As I tried to trace the very meaning of science-fiction, I see that it dates back many years ago, with a Syrian-born Greek satirist (Britannica Encyclopedia), to Jules Verne and Edgar Allan Poe. While in British Science Fiction we find the names of Robert Louis Stevenson and H.G. Wells, In the United States of America there are Hugo Gernsback and John W. Campbell. After the Second World War, with the advent of the atomic bomb and cold war, the science fiction boomed. It became more sophisticated, more urbane and satiric. Major science fiction themes are about utopias and dystopias, alternate societies, sex and gender, alien lives, space travel and time travel, parallel universes and realities.

However, the modern figures of science fiction from whom Vonnegut is influenced a lot is Aldous Huxley and George Orwell. In Huxley's "Brave New World", an intellectual dissident is singled out and exiled by fatuous world rules anxious to preserve their numbing status quo. Whereas, George Orwell's "1984" reflects his profound suspicion of the totalitarian potential of modern technology. In his view, science can be dangerous as well as beneficial.

Following the lead of Huxley's "Brave New World", Vonnegut uses the conventions of science fiction to force his readers to think more deeply about the world we live in. Like Huxley, Vonnegut is not interested in high-tech gadgets for their own sake, nor does he describe future civilizations just to please the readers. Instead, he imagines other worlds because they allow him to point out what is wrong with contemporary society.

When asked to name his favourite writer, Vonnegut says the name of Orwell, because as he says in an interview, he likes "His concern for the poor, I like his socialism, I like his simplicity". (Allen, Conversations, 53). He even uses some of Orwell's ideas in "God Bless you, Mr. Rosewater", when the senator Rosewater criticizes the idea that the rich deserve everything they have and they should not share anything with the poor, because that makes them lazy.

In this sense, what Vonnegut takes from science fiction as a genre, is not merely the techniques and style, but he makes them his owns, to better express his ideas. He does not serve to science fiction, but it is science fiction that serves to him, to criticize the present through the future, to speak about the dehumanization of the society and the replacement of human beings with machines, the themes of apocalypse and chaotic universe. What Vonnegut does in fact is to create a new reality that points out all the problems with the real one and turns science fiction into his own art. Even the critic Robert Scholes says that "the most appropriate fiction that can be written in the present or the immediate future is fiction that takes place in future time".

Vonnegut's main elements in his novels were always science and scientists. As he was trained and then worked in public relations at General Electrics, he was encouraged to write about the role of science and technology in American society. He starts with "Player Piano" (1952), his first novel, has as main theme the facing of the American man to the new developed technology. The main character, Paul Proteus, who is an engineer is very happy at first. But as technology starts replacing people, after computers choose people to get to work, after his cat is eaten by a technical gadget, he wants to escape. But it is now easy to escape such a society. In fact, "Player Piano" is set in the future, and it reveals an "utopian" society, where the government controls everything. The author challenges Paul by narrating a parallel plot the story of Shah of Bratpur, who comes for a visit and is shocked by the life people do in America. The question the author poses is about the future of the American society if they follow this path of mechanization. Everything is computerized and the escape is difficult. In "Player Piano", Vonnegut gives us a vision of the future that was intended to warn the American society about the perils of their worship in modern technology.

Vonnegut treats the theme of technology and scientist in a more interesting way in the novel "Cat's Cradle" (1963). After publishing the first two novels, "Cat's Cradle" started as a project for his thesis. Even though it was rejected by his college, he still decided to publish it as a novel and he did right, because with this one, he moved from being an obscure writer to a well-known one. Here, Vonnegut's interest is not on science more than it is on the people who worship science mostly, scientists. The story starts with the narrator, who wants to write a story about the day the world ended, which refers to the bombing of Hiroshima. He wants to ask one of the creators of the bomb, dr. Hoenikker. He does not find the scientist, but he gets to know his children. Even though he is dead, he has left a legacy that can be deadly to his children but also to the world. He had created a combination of molecules, called ice-9 that when in contact to water, turns everything into ice, every molecule. He divided it into three parts and gave one to each of them. So, now it was important to find them, because the world was in front of a big threat in the hands of three common people. The narrator, asking us to call him Jonah, arrives in the island of San Lorenzo, where he gets to know and that to be part, of a new religion called Bokononism, based on harmless untruths. But at the end, one of the parts of ice- 9 ends in the water and everything ends 
up in ice. So, the idea of Kurt Vonnegut in this novel is that it is not only the American society facing the difficulties of mechanization, but the main threat is for the world now, precisely by the people who invented the atomic bomb, and still keep on inventing dangerous chemicals.

Even in "Deadeye Dick", Vonnegut reacts to an even more horrific weapon, the neutron bomb, which was designed to kill people while leaving buildings intact. Rudy Waltz, the novel's protagonist, accidentally kills a pregnant woman by firing his father's gun out of an open window. The novels suggest that scientists who place nuclear weapons in the hands of politicians are just as irresponsible as the father who let a ten-year-old have access to a gun.

However, it is inaccurate to say that Vonnegut is against scientists and against technology. He admits that human beings are curious about everything and that for Vonnegut is something good. He also recognizes the joy that comes from scientific inquiry and discovery. In recent interviews and speeches, he recognized the fact that scientists were becoming more aware about the interest of people first and about the social and moral effects of their discoveries and that made him happy.

Another of the most important themes of Kurt Vonnegut's fiction is that of free will. Moreover, the best means to explain what free will is for him is that of space and time travel. Most of Vonnegut's characters suffer from a lack of courage, or when they find that inner strength, the circumstances just forbid them. For example, Paul Proteus in "Player Piano" can not change. Alternatively, Jonah, at "Cat's Cradle", he can not escape his destiny. However, "Sirens of Titan" is where Vonnegut best uses this technique. He begins by revealing that "the following is a true story from the Nightmare Ages, falling roughly, give or take a few years, between the Second World War and the Third Great Depression." (Sirens of Titan, 8) In this way the story examines the distant past and it allows the writer to make the story more believable. Malachi Constant, the protagonist, moves in time and space. He goes to another planet, with aliens and there he has a sexual intercourse with a woman and he has a son. In this planet, he lives with a robot called Salo, where sometimes it is more human than his human friend Rumfoord. In "Sirens of Titan", you can find everything: the kidnapping of Earthlings by aliens, the use of superior spaceships able to exceed the speed of light by some version of "space warp", a whole new universe and a trip beneath the surface of a planet where strange creatures are encountered.

This technique serves more to his best novel, "Slaughterhouse-Five". It is based on his experience in Dresden, where he was kept as a prisoner of war in a slaughterhouse and then he witnessed the bombing of Dresden and the death of a lot of innocent people. For many years, it was an experience that tortured him. He wanted to write about it, but it was impossible, because "there is nothing intelligent to say about a massacre".(Slaughterhouse-Five, 24) As he says in the beginning of the novel, he failed attempts at writing a traditional narrative about Dresden, with a beginning, middle and end. He had to find a new narrative and the best that could serve him was time travel and space travel, which can be also considered as a telegraphic-schizophrenic technique. Bill Pilgrim, who is the protagonist of the novel, as his name infers, makes a whole pilgrimage in time and space. At one moment, we find him a doctor in USA, then as a prisoner of war in Germany, then with his best friend of the war and at another moment he is kept prisoner by aliens of the planet Tralfamador. He has become "unstuck in time". Sometimes, when reading the novel you must be very careful, because you can lose track of the story. But this is the intention of the writer and that is what science-fiction helps him more. So, science fiction techniques do not only serve to the idea, but they serve too much even to the structure, especially to the narration. His narration is not sequential. It jumps around in time and through space. Events are not presented in linear order. Transitions are abrupt, narrative sections, small, several paragraphs long. Sentences are usually short, and sentence structure is simple. With the usage of science fiction, Vonnegut talks about human psychological responses to trauma and about alternative ways of exercising human consciousness.

However, the most interesting means of science fiction for Vonnegut is the recreation of reality through the invention of new realities. In this way, he can easily present all the problems of the present, criticize it and give solutions for the future. As in "Sirens of Titan", also in "Slaughterhouse-Five", Vonnegut use the typical science fiction themes, planets and extraterrestrials. The most well-known is that of Tralfamador. In both these novels, the protagonists are kept by aliens in these planets, which in fact are inhabited by these robots and extraterrestrials, that find some ways of communicating with both Malachi and Bill. What helps the reader understand more about the universe and reality of Vonnegut is precisely this discussion of Bill to the Tralfamadorians. In their conversations, they give some responses to Bill, explanations, even for matters like life and death. "There are no telegrams in Tralfamadore. But you're right: each clump of symbols is a brief, urgent message - describing a situation, a scene. We Tralfamadorians read them all at once, not one after the other. There isn't any particular relation between the messages, except that the author has chosen them carefully, so that, when seen all at one time, they produce an image of life that is beautiful and surprising and deep. There is no beginning, no middle, no end, no suspense, no moral, no causes, no effects. What we love in our books are the depths of many marvelous moments seen all at one time." (Slaughterhouse-Five, pg. 76) So, for Tralfamadorians, 
neither life, nor death exist. They are just moments, seen all at once, because imposing conditions of time and space take the meaning of these events.

The matter of science fiction has always been part of the debates among critics, concerning the definition, but mostly if it considered high literature or not. Even though at first Vonnegut, was considered to be a science fiction writer and critics didn't take him seriously, with his art he could turn it into what many critics consider it "high literature". The critic, Stanley Schatt, also tries to answer this dilemma: "While science fiction is an element in almost every Vonnegut novel, the blurring of the fine line between science and fiction during the past two decades is one of the reasons he has become acceptable to academe." (Schatt, 1977, pg. 18)

Science fiction has served Vonnegut to express his ideas, but at the same time to crate new narratives. The postmodern reality needed new narratives, and science fiction provided Vonnegut with the best means to express the atrocities he had faced in WW II, the new reality of the American society towards the worship of new technology and the threat the world faces by these "irresponsible" scientists. Todd Davis, one of the scholars who studied Vonnegut's fiction, focuses more on the humanist and postmodernist part of the writer. "Vonnegut, like Huxley and Orwell, concerns himself with science and sociology, but the manner in which he approaches his subjects differ radically from his precursors that to speak of their work in the same breath is oxymoronic. The more than half century that has passed since the publication of Player Piano affords us the critical hindsight necessary to discern the absurdly satiric nature of Vonnegut's social criticism." (Davis, 2006, pg. 41) Even the critic Jerome Klinkowitz comes to terms with Davis, when he says that "...the mechanics of science fiction the author makes it equally laughable", because "traditional science fiction takes its science seriously - too seriously for Vonnegut's purposes since the point he wants to make are not about machinery but about people." (Klinkowitz, 2004, pg.183) So, for Vonnegut, science fiction is not just for the sake of the form and content, but also serves Vonnegut for his bitter humor. It becomes part of a new narrative, of a postmodern narrative.

\section{References}

Allen, William Rodney, ed. Conversations with Kurt Vonnegut. Jackson: UP of Mississippi, 1988.

Bloom, Harold, ed. Modern Critical Views: Kurt Vonnegut. Philadelphia, PA: Chelsea House, 2000.

Klinkowitz, Jerome. The Vonnegut Effect. University of South Carolina Press, 2004.

Marvin, Thomas. Kurt Vonnegut, A Critical Companion. Greenwood Press, 2002.

Schatt, Stanley. Kurt Vonnegut, Jr. Boston: Twayne, 1976.

Scholes, Robert. Structural Fabulation: An essay on the Fiction of the Future. University of Notre Dame Press, 1975

Todd, Davis. Kurt Vonnegut's Crusade: Or how a postmodern harlequin preached a new kind of humanism. State University of New York, 2006.

http://www.britannica.com/EBchecked/topic/black-humour.

http:// www. Merriam-Webster encyclopedia.com

Vonnegut, Kurt Jr. Player Piano. New York: Charles Scribner's Sons, 1952.

The Sirens of Titan. New York: Dell, 1959.

Cat's Cradle, New York: Holt, Rinehart and Winston, 1963.

Slaughterhouse-Five. New York: Delacorte Press, 1969.

Wampeters, Foma and Granfalloons: Opinions. New York: Delacorte Press, 1974 